\title{
STRATEGI PENGEMBANGAN USAHA IKAN NILA DI KABUPATEN KUANTAN SINGINGI PROPINSI RIAU
}

\author{
Sri Ayu Kurniati Dan Jumanto \\ Fakultas Pertanian Universitas Islam Riau Jl. Kaharuddin Nasution No. 113 \\ Pekanbaru 28284 \\ Email: sriayukurniati@agr.uir.ac.id
}

Pembangunan perikanan bertujuan untuk mewujudkan stabilitas ekonomi yang seimbang sekaligus pengembangan pembangunan desa dan meningkatkan taraf hidup pengusaha ikan nila. Diperlukan strategi usaha yang tepat dan dapat diandalkan agar budidaya ikan nila ini berkesinambungan dan perekonomian masyarakat meningkat. Tujuan penelitian ini adalah untuk menganalisis: 1) Karakteristik pengusaha dan profil usaha ikan nila, 2) Strategi pengembangan usaha ikan nila. Penelitian ini menggunakan metode survei di Kecamatan Singingi Hilir Kabupaten Kuantan Singingi dengan jumlah responden 60 orang. Metode yang digunakan adalah deskriptif kuantitatif analisis SWOT. Hasil penelitian menyatakan bahwa karakteristik pengusaha rata-rata berumur 49 tahun, lama pendidikan hanya 6 tahun, pengalaman berusaha ikan sekitar 4-8 tahun, dan jumlah tanggunngan keluarga umumnya 4 jiwa. Skala usaha umumnya skala kecil yang dikelola oleh pengusaha sendiri,dengan jumlah modal awal dan penggunaan tenaga kerja sedikit. Strategi pengembangan usaha ikan nila menyatakan bahwa usaha ini berada pada kuadran ketiga sehingga dapat menjalankan stratgi WO, diantaranya memberikan gambaran tentang usaha ikan nila kepada pihak terkait agar mendapat penyaluran kredit, memperluas jangkauan pemasaran dengan cara meningkatkan kualitas produk ikan nila yang dihasilkan, meningkatkan promosi produk unggulan untuk memenuhi permintaan pasar, dan memberikan bonus pada karyawan jika penjualan produksi meningkat untuk menambah semangat kerja.

Kata Kunci: Strategi, Ikan Nila, Analisis SWOT

\section{PENDAHULUAN}

Sub sector perikanan mempunyai peran dalam menunjang perkembangan perekonomian nasional, khususnya keuntungan nyata yang dapat di rasakan masyarakat yaitu sebagai sumber lapangan pekerjaan, meningkatkan pendapatan produsen, dan sebagai sumber pangan hewani yang bernilai gizi yang tinggi.Pembangunan perikanan pada saat ini diarahkan untuk peningkatan kontribusi subsektor perikanan dalam menunjang terciptanya pertanian yang maju, efisien, dan tangguh. Selanjutnya, pembangunan perikanan bertujuan untuk mewujudkan stabilitas ekonomi yang seimbang antara industri dan pertanian yang mendukung, sekaligus pengembangan pembangunan desa dan meningkatkan taraf hidup pengusaha ikan. Salah satu upaya untuk meningkatkan produksi perikanan

\section{3 | Strategi Pengembangan Usaha Ikan Nila Di Kabupaten Kuantan Singingi Propinsi Riau}


adalah melalui teknik budidaya dan pola pengembangan dengan cara ekstensifikasi dan intensifikasi terutama di daerah-daerah yang memiliki potensi dan prospek yang cukup tinggi, baik budidaya laut, pantai, danau, dan air tawar.

Nilai komersial yang cukup menjanjikan dari sub sektor perikanan banyak tersedia dari sejumlah spesies ikan, salah satunya adalah ikan Nila. Nilai produksi perikanan di Propinsi Riau dapat dijumpai pada perikanan laut, perairan umum, dan budidaya untuk berbagai jenis komoditas. Nilai tertinggi berdasarkan data Dinas Perikanan dan Kelautan tahun 2015 didapat dari perairan laut sebesar Rp 2.469.145,037. Sementara itu produksi perikanan di Propinsi Riau tahun 2015 yang berasal dari berbagai tempat pembudidayaan terlihat pada gambar berikut:

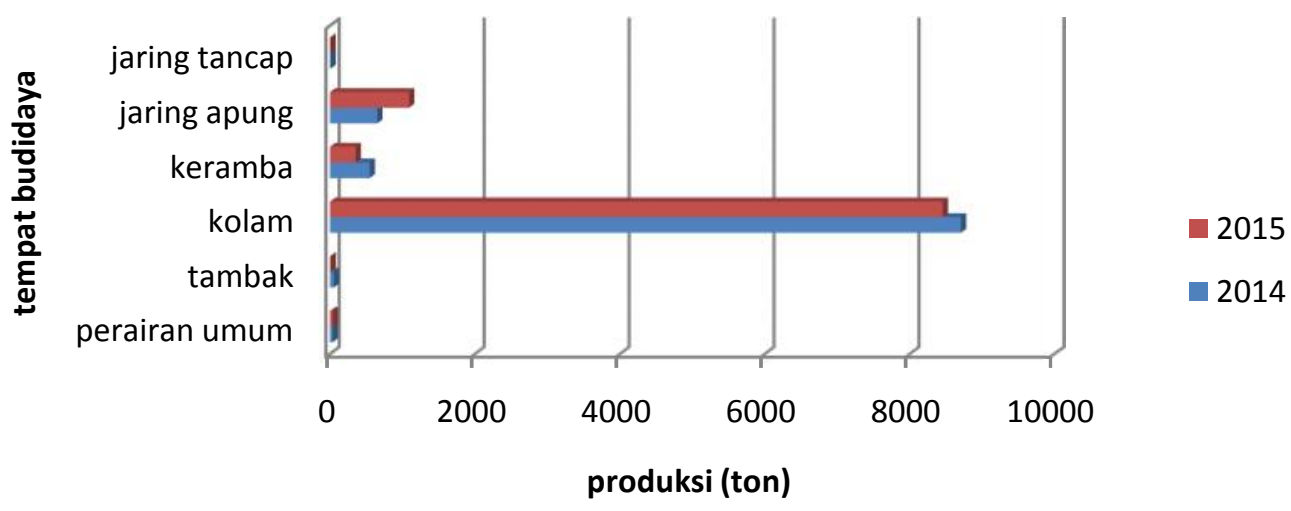

Gambar 1.Produksi Perikanan Propinsi Riau Tahun 2014-2015

Berdasarkan Gambar 1 terlihat bahwa jumlah produksi terbesar diperoleh dari pembudidayaan ikan di kolam yakni lebih dari 8.000 ton, hal ini dikarenakan cara mengusahakan ikan nila yang lebih sederhana dan mudah dilakukan oleh sebagian besar pengusaha ikan. Sedangkan produksi terendah dihasilkan oleh perairan umum, tambak, dan jaring apung tancap.

Kabupaten Kuantan Singingi merupakan salah satu wilayah yang turut serta menyumbang hasil perikanan bagi produksi perikanan total di Propinsi Riau. Pada tahun 2015 hasil dari budidaya ikan nila di perairan umum berjumlah 374,2 ton, budidaya kolam 3.190,03 ton, dan budidaya keramba berjumlah 63,54 ton. Ternyata budidaya di kolam juga memberikan hasil produksi nila tertinggi.

Jumlah produksi ikan yang tinggi memiliki keterkaitan erat dengan tingkat konsumsi masyarakat terhadap sumber protein hewani ikan, karena selain memiliki nilai gizi yang tinggi, mengkonsumsi ikan juga dapat meningkatkan 14 | Strategi Pengembangan Usaha Ikan Nila Di Kabupaten Kuantan Singingi Propinsi Riau 
kecerdasan dan daya ingat. Kebutuhan standar konsumsi ikan rata-rata adalah 14,3 $\mathrm{kg}$ per kapita per tahun atau 1,2 kg per kapita per bulan (BPS, 2015). Artinya, jumlah produksi yang tersedia masih sangat kurang untuk dapat memenuhi kebutuhan masyarakat terhadap konsumsi ikan. Kebutuhan ikan bagi masyarakat sangatlah penting sehingga wajar jika usaha perikanan harus dikembangkan (Murtidjo, 2005). Prioritas pada hal-hal yang perlu mendapat perhatian diantaranya pengelolaan air, ketersediaan saprodi, cara pembudidayaan, dan penggunaan pakan. Namun masalah umum yang senantiasa terjadi adalah tingkat kemampuan dan ketrampilan pengusaha ikan yang masih rendah, penggunaan faktor produksi yang belum efisien, dan rantai tataniaga yang sulit dan panjang menyebabkan nilai perbandingan antara biaya produksi yang dikeluarkan masih sangat bessar dibandingkan dengan keuntungan yang diterima.

Dukungan dari kondisi alam perikanan di Kabupaten Kuantan Singingi memiliki prospek secara ekonomi untuk pengembangan budidaya ikan nila. Terdapat beberapa kecamatan yang memproduksi ikan nila lebih banyak daripada produksi ikan jenis lainnya, diantaranya Kecamatan Gunung Toar, Singingi, Singingi Hilir, Kuantan Tengah, Benai, Kuantan Hilir, Pangean, Logas, dan dari semua kecamatan tersebut Kecamatan Kuantan Tengah memperoleh hasil produksi nila tertinggi yakni 991,57 ton. Usaha budidaya ikan nila tidak hanya sekedar usaha pemeliharaan ikan tetapi usaha yang meliputi keseluruhan aspek sumberdaya hayati perairan.

Salah satu tantangan yang perlu mendapat perhatian adalah belum optimalnya tingkat pemanfaatan sumberdaya perikanan dibandingkan dengan besarnya potensi yang tersedia. Diperlukan strategi usaha yang tepat, mantap, dan dapat diandalkan agar budidaya ikan nila ini berkesinambungan dan perekonomian masyarakat meningkat. Langkah awal menyusun strategi pengembangan usaha adalah dengan menganalisis lingkungan internal yang mencakup faktor kekuatan dan kelemahan pengusaha ikan dan lingkungan eksternal meliputi pemanfaatan peluang dan menghindari atau meminimalisir ancaman yang berasal dari luar.

Berdasarkan latar belakang tersebut, maka tujuan penelitian ini adalah: 1) menganalisis karakteristik pengusaha ikan dan profil usaha ikan nila di 15 | Strategi Pengembangan Usaha Ikan Nila Di Kabupaten Kuantan Singingi Propinsi Riau 
Kecamatan Singingi Hilir, 2) menganalisis strategi pengembangan usaha ikan nila di Kecamatan Singingi Hilir. Penelitian ini diharapkan dapat bermanfaat bagi masyarakat khususnya pengusaha ikan nila dalam mengembangkan usahanya dan bahan pertimbangan bagi pemerintah dalam mengambil kebijakan khususnya dalam pembinaan dan pengembangan usaha ikan nila.

\section{METODE PENELITIAN}

Penelitian dilakukan dengan metode survei di Kecamatan Singingi Hilir Kabupaten Kuantan Singingi dengan pertimbangan bahwa di daerah tersebut banyak terdapat pengusaha ikan yang mengusahakan usahataninya secara komersial dan berkelanjutan. Jumlah populasi adalah 60 orang dan secara sensus semua populasi dijadikan responden penelitian.

Data yang dikumpulkan terdiri dari data primer dan data sekunder. Data primer diperoleh dari wawancara langsung dengan menggunakan daftar pertanyaan, meliputikarakteristik pengusaha ikan (umur, lama pendidikan, pengalaman berusaha, dan jumlah tanggungan keluarga) dan profil usaha (skala usaha, penggunaan modal, dan jumlah tenaga kerja).

Sementara data sekunder merupakan data yang telah dipublikasi yang diperoleh dari instansi terkait, seperti Dinas Perikanan, BPS, Kantor Camat Singingi Hilir, meliputi keadaan umum daerah penelitian (letak dan geografis daerah, jumlah penduduk, tingkat pendidikan, sosial, ekonomi dan potensi perikanan khususnya ikan nila), dan kondisi perkembangan usaha perikanan.

\section{Analisis Data}

Untuk mengetahui karakteristik pengusahaikan dan profil usahatani digunakan analisis deskriptif kualitatif. Data tersebut ditampilkan dalam bentuk tabel atau gambar, meliputi: umur, lama pendidikan, pengalaman berusaha, jumlah tanggungan keluarga, skala usaha, penggunaan modal, dan jumlah tenaga kerja.Sedangkan untuk memformulasikan strategi pengembangan usaha digunakan analisis SWOT (Strength, Weaknesses, Opportunities, Threats) yang akan mempermudah merumuskan berbagai strategi baru dengan mengelompokan masing-masing permasalahan ke dalam tabel (Rangkuti, 2006).

Analisis SWOT dilakukan dengan mengidentifikasi faktor internal dan faktor eksternal yang kemudian ditabulasikan ke dalam tabel IFAS (Internal 16 | Strategi Pengembangan Usaha Ikan Nila Di Kabupaten Kuantan Singingi Propinsi Riau 
strategic Factor Analysis Summary) untuk kerangka Strength (kekuatan) dan Weaknesses (kelemahan) dan EFAS (External strategic FactorAnalysis Summary) untuk kerangka Opportunities (peluang) dan Threats (ancaman). Setiap unsur SWOT dihubungkan keterkaitannya dengan simbol SO (Strength-Opportunities), ST (Strength-Threats), WO (Weaknessnes-Opportunities), dan WT (WeaknessesThreats).

Penentuan alternatif strategi yang utama dikakukan dengan pembobotan dan tetap memperhatikan unsur SWOT yang terkait. Jumlah skor pembobotan akan menentukan rangking alternatif strategi atau kebijakan yang akan diambil dalam pengembangan usaha ikan nila.

\section{HASIL DAN PEMBAHASAN}

\section{Karakteristik Pengusaha Ikan dan Profil Usaha Ikan Nila}

A.Karakteristik Pengusaha ikan

Terdapat empat faktor yang mempengaruhi karakteristik dan kemampuan pengusaha ikan dalam mengelola usaha budidaya ikan nila yaitu umur, tingkat pendidikan, pengalaman berusaha, dan jumlah tanggungan keluarga.

a) Umur, mempengaruhi pola pikir pengusaha dalam berusaha. Berdasarkan penelitian diketahui bahwa umur responden berada pada kisaran 31-59 tahun atau rata-rata berumur 49 tahun. dan tergolong umur produktif. Umur pengusaha yang produktif berhubungan erat dengan tingkat produktivitasnya. Apabila seseorang berada dalam usia produktif maka produktivitas kerjanya masih dapat ditingkatkan sehingga hasil pekerjaan yang diperoleh semakin banyak dan pendapatan akan meningkat.

b) Lama Pendidikan, berpengaruh pada pemahaman dan pengadopsian ilmu dan teknologi juga pada rasionalitas pengambilan keputusan terhadap segala kondisi akibat perubahan zaman. Responden umumnya berpendidikan rendah yaitu lama pendidikan 6 tahun. Rendahnya tingkatan pendidikan pengusaha ikan disebabkan karena keterbatasan ekonomi dan kurangnya kemauan dalam upaya menempuh jenjang pendidikan yang lebih tinggi. Tingkat pendidikan berkaitan erat dengan kemampuan seseorang untuk memberikan keputusan apakah bekerja atau tidak dalam rangka memperbaiki taraf hidup keluarga. Rendahnya tingkat pendidikan

17 | Strategi Pengembangan Usaha Ikan Nila Di Kabupaten Kuantan Singingi Propinsi Riau 
pengusaha ikan menunjukkan bahwa kualitas sumberdaya manusia tidak memadai di dalam pengembangan usaha ikan nila dan akses kesempatan kerja di luarsektor pertanian.

c) Pengalaman usaha, berpengaruh pada kemampuan, keahlian dan ketrampilan pengusaha dalam budidaya usahatani. Pengalaman berusaha ikan nila oleh sebagian besar responden berkisar antara 4-8 tahun. Artinya pengusaha ikan nila cukup berpengalaman dalam menjalankan aktivitas usaha budidaya ikan sehingga memiliki pengetahuan yang baik terhadap kelangsungan hidup usahanya.

d) Jumlah Tanggungan Keluarga, berpengaruh pada kemampuan pengelolaan ekonomi keluarga, apabila dalam keluarga tersebut banyak terdapat anggota keluarga berusia produktif maka beban yang ditanggung kepala keluarga akan berkurang karena pada usia tersebut anggota keluarga dapat bekerja dan membantu meningkatkan pendapatan keluarga. Hasil penelitian memperlihatkan jumlah tanggungan keluarga rata-rata 4 jiwa.

\section{B. Profil Usaha Ikan Nila}

Profil usaha pengusaha ikan nila meliputi besaran skala usaha, penggunaan modal dan jumlah tenaga kerja, dimana kesemuanya dalam kondisi yang terbatas. Skala usaha budidaya ikan nila umumnya adalah skala kecil yang dikelola oleh pengusaha sendiri. Penggunaan modal juga modal sendiri dengan jumlah modal awal rata-rata pengusaha adalah Rp 7.000.000. Jumlah tenaga kerja yang dimiliki tidak banyak dan pemakaian tenaga kerja dari luar keluarga dilakukan dengan sistem upah per panen, perhitungan jam kerja yang digunakan dihitung berdasarkan tahapan kerja seperti penebaran benih, pemberian pakan, perawatan, pemeliharaan dan pemanenan ikan

\section{Strategi Pengembangan Usaha Ikan Nila}

Terlebih dahulu perlu diidentifikasi faktor internal dan eksternal usaha ikan nila di Kecamatan Singingi Hilir. Faktor internal terdiri dari kekuatan dan kelemahan sedangkan faktor eksternal terdiri dari peluang dan ancaman. Berikut ini adalah rincian dari faktor internal pengusaha ikan nila:

18 | Strategi Pengembangan Usaha Ikan Nila Di Kabupaten Kuantan Singingi Propinsi Riau 
Tabel 1. Faktor Internal Usaha Ikan Nila di Kecamatan Singingi Hilir, 2015

\begin{tabular}{|c|c|c|c|}
\hline Kekuatan (Strength) & Bobot & Rating & Skor \\
\hline 1. Sumberdaya air mencukupi & 0,10 & 4 & 0,40 \\
\hline 2. Harga terjangkau oleh konsumen & 0,08 & 2 & 0,16 \\
\hline 3. Lokasi usaha dekat ibukota kecamatan & 0,05 & 3 & 0,15 \\
\hline 4. Sarana transportasi tersedia & 0,09 & 2 & 0,18 \\
\hline 5. Potensi lahan budidaya besar & 0,05 & 2 & 0,10 \\
\hline 6. Jumlah tenaga kerja memadai & 0,10 & 3 & 0,30 \\
\hline Sub total & 0,47 & & 1,29 \\
\hline \multicolumn{4}{|l|}{ Kelemahan (Weaknesses) } \\
\hline 1. Kurang modal & 0,12 & 4 & 0,48 \\
\hline 2. Jumlah benih terbatas & 0,12 & 4 & 0,48 \\
\hline 3. Tingginya harga pakan & 0,07 & 1 & 0,07 \\
\hline 4. Pemasaran hanya lokal & 0,10 & 3 & 0,30 \\
\hline 5. Belum optimal informasi dan promosi & 0,05 & 3 & 0,15 \\
\hline 6. Kurang motivasi kerja bagi tenaga kerja & 0,07 & 2 & 0,14 \\
\hline Sub total & 0,53 & & 1,62 \\
\hline Total & 1,00 & & $-0,33$ \\
\hline
\end{tabular}

Berdasarkan Tabel 1 dapat diketahui bahwa bobot faktor kekuatan terbesar berada pada indikator sumberdaya air dan jumlah tenaga kerja yang memadai, namun dari keduanya skor yang tertinggi adalah pada sumberdaya air. Hal ini terjadi karena pengusaha ikan memperoleh air dari aliran sungai, dimana air tersebut kemudian ditampung pada kolam khusus air deras yang akan mengalir terus menerus dalam jumlah tertentu ke kolam-kolam budidaya ikan nila. Pembudidaya ikan menggunakan kolam air deras pada prinsipnya memanfaatkan aliran air yang relative besar untuk meningkatkan daya dukung kolam guna menunjang pertumbuhan ikan yang dipelihara (Sucipto, 2005).

Sementara pada faktor kelemahan terlihat bahwa indikator pengusaha ikan yang kurang modal dan jumlah benih yang terbatas memiliki skor tertinggi yakni 0,48. Modal yang dimiliki pengusaha ikan sangat terbatas karena keadaan ekonomi yang lemah sehingga umumnya tidak berani melakukan pinjaman ke bank. Pengusahajuga menganggap bahwa usaha ikan nila adalah usaha sampingan karena pekerjaan utamanya adalah pengusaha dan buruh karet.

Setelah didapatkan skor dari kedua faktor internal tersebut, maka langkah berikutnya adalah menghitung skor selisih dengan cara mengurangi skor kekuatan dan skor kelemahan dan diperoleh nilai -0,33 (negatif). Artinya antara kekuatan dan kelemahan ternyata kelemahan internal pengusaha lebih

19 | Strategi Pengembangan Usaha Ikan Nila Di Kabupaten Kuantan Singingi Propinsi Riau 
besar daripada kekuatan yang dimiliki. Sehingga perlu adanya strategi untuk memperkecil kelemahan agar meningkat kekuatan. Rincian faktor eksternal tertuang pada tabel berikut:

Tabel 2. Faktor Eksternal Usaha Ikan Nila di Kecamatan Singingi Hilir

\begin{tabular}{|c|c|c|c|}
\hline Peluang (Opportunities) & Bobot & Rating & Skor \\
\hline 1. Tingginya permintaan produk hasil & 0,13 & 4 & 0,39 \\
\hline 2. Permintaan benih tinggi & 0,06 & 4 & 0,24 \\
\hline 3. Peningkatan pendapatan masyarakat & 0,10 & 3 & 0,30 \\
\hline 4. Peningkatan konsumsi ikan & 0,10 & 4 & 0,40 \\
\hline 5. Peningkatan nilai produk dan nilai tambah & 0,08 & 2 & 0,16 \\
\hline $\begin{array}{l}\text { produk olahan } \\
\text { 6. Perluasan kesempatan kerja }\end{array}$ & 0,05 & 3 & 0,15 \\
\hline Sub total & 0,52 & & 1,64 \\
\hline \multicolumn{4}{|l|}{ Ancaman (Threats) } \\
\hline 1. Tersedianya ikan-ikan laut segar & 0,08 & 2 & 0,16 \\
\hline 2. Bencana alam & 0,10 & 4 & 0,40 \\
\hline 3. Harga produk yang tidak stabil & 0,05 & 1 & 0,05 \\
\hline 4. Belum ada konsumen tetap & 0,14 & 3 & 0,42 \\
\hline 5. Persaingan harga pesaing & 0,05 & 2 & 0,10 \\
\hline 6. Dampak limbah terhadap lingkungan & 0,06 & 1 & 0,06 \\
\hline Sub total & 0,48 & & 1,19 \\
\hline Total & 1,00 & & 0,45 \\
\hline
\end{tabular}

Tabel 2 memperlihatkan bahwa skor peluang terbesar bagi pengusaha ikan nila adalah peningkatan konsumsi ikan pada masyarakat. Masyarakat menyadari bahwa nilai gizi yang tinggi dapat diperoleh dari mengkonsumsi protein yang dihasilkan oleh ikan, sedangkan skor terendah terdapat pada indikator perluasan kesempatan kerja. Masyarakat lebih tertarik untuk bekerja di sektor non pertanian dengan harapan memperoleh pendapatan tinggi daripada mengusahakan budidaya ikan.

Faktor ancaman yang memberikan skor tertinggi adalah belum adanya konsumen tetap yang kontinyu membeli hasil produksi budidaya ikan nila. Konsumen umumnya adalah masyarakat sekitar yang datang ke lokasi kolam budidaya dan melakukan pembelian di tempat. Selebihnya hasil produksi akan dibawa pengusaha ikan ke pasar untuk dijual pada pedagang pengecer.

Selisih dari skor peluang dan skor ancaman diperoleh nilai sebesar 0,45 (positif). Artinya pengusaha ikan memiliki peluang untuk mengembangkan usaha budidaya ikan nila namun tetap memperhatikan beberapa indikator ancaman. Harapan pengusaha ancaman yang ada hendaknya dapat diminimalisir dengan memperbesar pemanfaatan peluang yang ada.

\section{I Strategi Pengembangan Usaha Ikan Nila Di Kabupaten Kuantan Singingi Propinsi Riau}


Perolehan nilai skor dari faktor-faktor internal sebesar-0,33 dan faktor eksternal sebesar 0,45 selanjutnya dapat dijadikan panduan dalam membuat kuadran SWOT. Usaha budidaya ikan nila di Kecamatan Singingi Hilir Kabupaten Kuantan Singingi berada pada kuadran ketiga yaitu memiliki sejumlah peluang besar yang impresif namun dihambat oleh kelemahan,seperti yang terlihat pada gambar beikut:

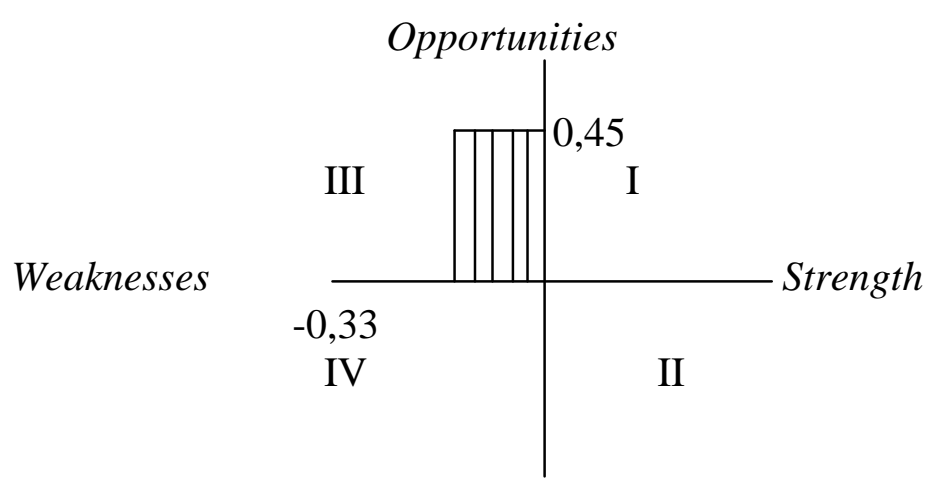

Threats

Gambar 2. Kuadran SWOT

Setelah mengetahui bahwa usaha budidaya ikan nila berada pada kuadran ketiga, maka langkah selanjutnya adalah menerapkan strategi kebijakan intensifatau strategi WO yaitu memperbaiki kelemahan internal dengan memanfaatkan peluang eksternal. Strategi yang dapat dikembangkan antara lain:

a) Memberikan gambaran tentang usaha ikan nila seperti karakteristik dan profil usaha kepada pihak terkait (lembaga keuangan) agar mendapat penyaluran kredit dengan biaya angsuran yang lebih murah

b) Memperluas jangkauan pemasaran tidak hanya untuk masyarakat sekitar lokasi budidaya dengan cara meningkatkan kualitas produk ikan nila yang dihasilkan

c) Meningkatkan promosi produk unggulan untuk memenuhi permintaan pasar, seperti disaat peringatan hari kemerdekaan, ulang tahun daerah, kegiatan bazar ataupun pameran

d) Memberikan bonus pada karyawan jika penjualan produksi meningkat untuk menambah semangat kerja karyawan

\section{1 | Strategi Pengembangan Usaha Ikan Nila Di Kabupaten Kuantan} Singingi Propinsi Riau 
Untuk lebih jelasnya hasil analisis SWOT terlihat pada tabel berikut:

Tabel 3. Hasil Analisis Matriks SWOT Usaha Ikan Nila

\begin{tabular}{|c|c|c|}
\hline$E F A S$ & 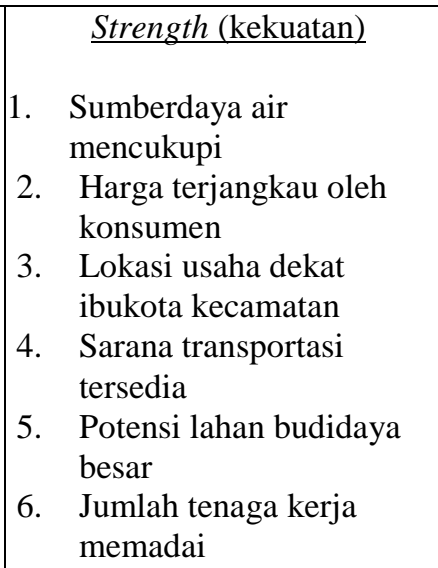 & $\begin{array}{l}\text { Weaknesses (kelemahan) } \\
\text { 1. Kurang modal } \\
\text { 2. Jumlah benih terbatas } \\
\text { 3. Tingginya harga pakan } \\
\text { 4. Pemasaran hanya lokal } \\
\text { 5. Belum optimal informasi } \\
\text { dan promosi } \\
\text { 6. Kurang motivasi kerja } \\
\text { bagi tenaga kerja }\end{array}$ \\
\hline $\begin{array}{l}\text { Opportunities (peluang) } \\
\text { 1. } \begin{array}{l}\text { Tingginya permintaan } \\
\text { pasar }\end{array} \\
\text { 2. Permintaan benih tinggi } \\
\text { 3. Peningkatan } \\
\text { pendapatan masyarakat } \\
\text { 4. Peningkatan konsumsi } \\
\text { ikan } \\
\text { 5. Peningkatan nilai } \\
\text { produk dan nilai } \\
\text { tambah produk olahan } \\
\text { 6. Perluasan kesempatan } \\
\text { kerja }\end{array}$ & 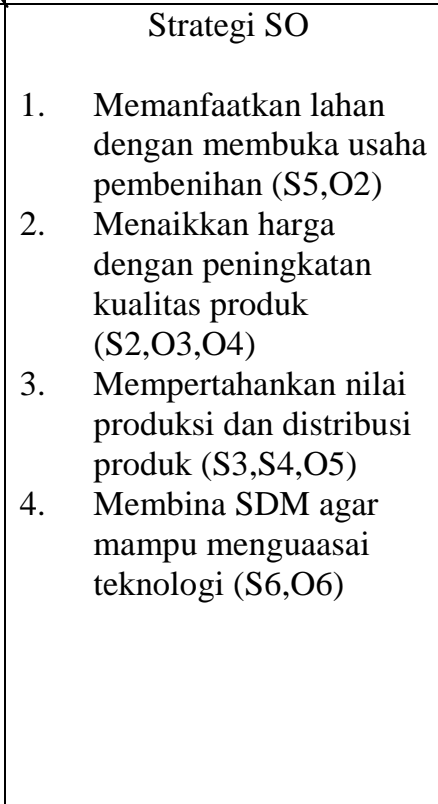 & 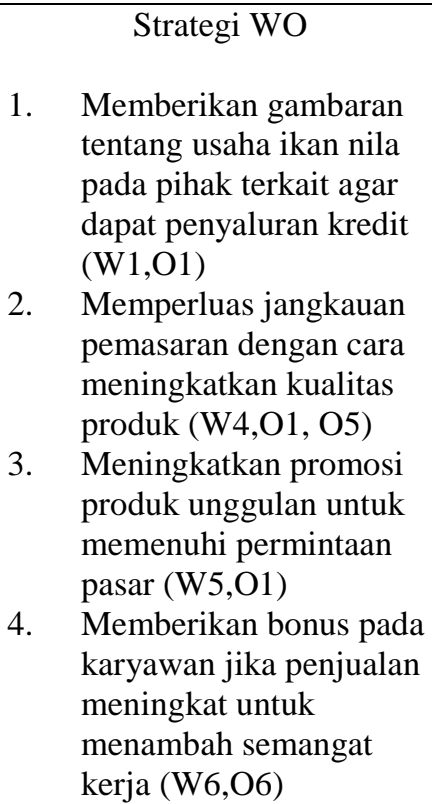 \\
\hline $\begin{array}{l}\text { Threats (Ancaman) } \\
\text { 1. Tersedianya ikan-ikan } \\
\text { laut segar } \\
\text { 2. Bencana alam } \\
\text { 3. Harga produk yang } \\
\text { tidak stabil } \\
\text { 4. Belum ada konsumen } \\
\text { tetap } \\
\text { 5. Persaingan harga } \\
\text { pesaing } \\
\text { 6. Dampak limbah } \\
\text { terhadap lingkungan }\end{array}$ & 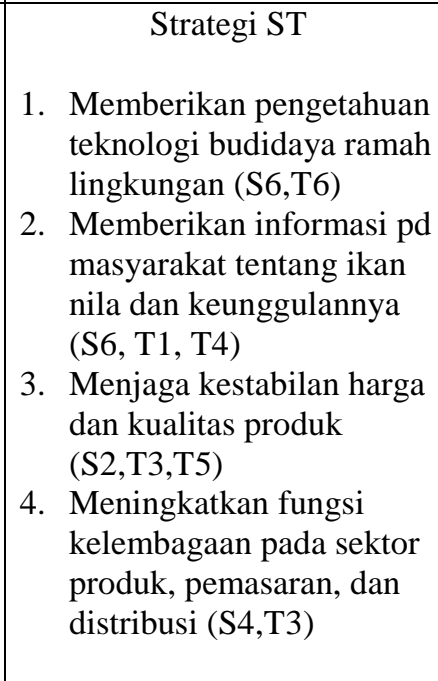 & \begin{tabular}{ll} 
& \multicolumn{1}{c}{ Strategi WT } \\
1. & Menginformasikan \\
manfaat mengkonsumsi \\
ikan nila (W5,T4) \\
2. & Menetapkan harga yang \\
kompetitif namun tetap \\
mendapat keuntungan \\
(S3,S5,T3) \\
3.
\end{tabular} \\
\hline
\end{tabular}

\section{2 | Strategi Pengembangan Usaha Ikan Nila Di Kabupaten Kuantan Singingi Propinsi Riau}




\section{Kesimpulan}

\section{KESIMPULAN DAN SARAN}

Berdasarkan uraian hasil penelitian, maka dapat disimpulkan beberapa hal:

1) Pengusaha ikan memiliki karakteristik yaitu rata-rata umurnya 49 tahun dan termasuk kedalam umur produktif, rata-rata berpendidikan rendah karena lama pendidikan hanya 6 tahun, pengalaman berusaha ikan sekitar 4-8 tahun, dan jumlah tanggunngan keluarga umumnya 4 jiwa. Skala usaha umumnya adalah skala kecil yang dikelola oleh pengusaha sendiri. Penggunaan modal juga modal sendiri dengan jumlah modal awal rata-rata pengusaha adalah Rp 7.000.000. Jumlah tenaga kerja yang dimiliki tidak banyak dan pemakaian tenaga kerja dari luar keluarga dilakukan dengan sistem upah per panen, perhitungan jam kerja yang digunakan dihitung berdasarkan tahapan kerja seperti penebaran benih, pemberian pakan, perawatan, pemeliharaan dan pemanenan ikan

2) Strategi pengembangan usaha ikan nila dengan menggunakan analisis SWOT menyatakan bahwa usaha ini berada pada kuadran ketiga sehingga dapat menjalankan stratgi WO, diantaranya memberikan gambaran tentang usaha ikan nila seperti karakteristik dan profil usaha kepada pihak terkait (lembaga keuangan) agar mendapat penyaluran kreditdengan biaya angsuran yang lebih murah, memperluas jangkauan pemasaran tidak hanya untuk masyarakat sekitar lokasi budidaya dengan cara meningkatkan kualitas produk ikan nila yang dihasilkan, meningkatkan promosi produk unggulan untuk memenuhi permintaan pasar, seperti disaat peringatan hari kemerdekaan, ulang tahun daerah, kegiatan bazar ataupun pameran, dan memberikan bonus pada karyawan jika penjualan produksi meningkat untuk menambah semangat kerja karyawan

\section{SARAN}

1) Pengusaha ikan mampu menemukan formula pakan yang murah namun berkualitas karena biaya produksi usaha ikan nila hampir 90\% dipergunakan untuk biaya pakan

\section{3 | Strategi Pengembangan Usaha Ikan Nila Di Kabupaten Kuantan} Singingi Propinsi Riau 
2) Pengusaha hendaknya menggunakan bibit unggul yang diperoleh dari induk yang unggul untuk mengurangi jumlah ikan yang mati karena hal ini akan mempengaruhi jumlah penjualan

3) pengusaha dapat meningkatkan perekonomian keluarga melalui strategi peningkatan jumlah produksi dan memaksimalkan penggunaan tenaga kerja

4) Adanya kerjasama pengusaha ikan dan instansi terkait dalam meningkatkan fungsi kelembagaan tani untuk mendapatkan informasi dan mengatasi kendala kualitas produksi, harga, pemasaran, dan transportasi

5) Adanya kegiatan penyuluhan dan pelatihan berbagai ketrampilan dari pemerintah berkenaan dengan usaha peningkatan produksi ikan nila

\section{DAFTAR PUSTAKA}

BPS. 2015. Tingkat Konsumsi Ikan per Kapita Penduduk. Jakarta

Dinas Perikanan dan Kelautan. 2015. Nilai Produksi Perikanan Laut, Perairan Umum, dan Budidaya. Pekanbaru

2015. Jumlah Produksi Perikanan. Kuantan Singingi

Fachriyan Hilmi Arija, Azis Nur Bambang, Muslim. 2014. Prospek Pengembangan Usaha Agribisnis Ikan Nila di kawasan Minapolitan Kabupaten Klaten Propinsi Jawa Tengah. Jurnal Agromedia, Vol. 33 No. 1. Universitas Diponegoro

Murtidjo, B, A. 2005. Beberapa Metode Pembenihan Ikan Air Tawar. Kanisius. Yogyakarta

Rahmawati, Hijjah dan Dede Hartono. 2012. Startegi Pengembangan Usaha Budidaya Ikan Air Tawar. Jurnal Penelitian Pengelolaan Sumberdaya Alam dan Lingkungan, Vol.1 No. 2 (129-134). Bengkulu

Rangkuti, F. 2006. Analisis SWOT: Teknik Membedah Kasus Bisnis. PT. Gramedia Pustaka Utama. Jakarta

Siregar Gustina, Hendra Suwarno, Samsidar. 2014. Strategi Pengembangan Ikan Nila. Jurnal Agrium, Vol.18 No. 3 Universitas Muhammadiyah Sumatera Utara

24 | Strategi Pengembangan Usaha Ikan Nila Di Kabupaten Kuantan Singingi Propinsi Riau 
Sucipto dan E. Prihartono. 2005. Pembesaran Ikan Nila Merah Bangkok di Keramba Jaring Apung, Kolam Air Deras, Kolam Air Tenang dan Keramba. Penebar Swadaya, Jakarta.

25 | Strategi Pengembangan Usaha Ikan Nila Di Kabupaten Kuantan Singingi Propinsi Riau 